\title{
Transient photosynthetic responses of nitrogen limited microalgae to nitrogen addition
}

\author{
Ivor R. Elrifi and David H. Turpin* \\ Department of Biology, Queen's University, Kingston, Ontario K7L 3N6, Canada
}

\begin{abstract}
The effect on photosynthesis of nitrogen addition to nitrogen limited phytoplankton was investigated in several species of algae. Addition of a nitrogen source induced suppression of carbon fixation in some species but not in others. The photosynthetic suppression response upon limiting nutrient addition is taxonomically widespread but appears to be species or strain specific. Discrepancies in previous reports are ascribed to differential phytoplankton responses and not to methodological differences. The physiological and ecological significances of the suppression phenomenon are considered.
\end{abstract}

\section{INTRODUCTION}

Recent evidence suggests that nutrients in aquatic systems may be distributed in patches (e.g. Lehman and Scavia, 1982). Understanding how phytoplankton respond to these transient nutrient regimes is of considerable importance in shaping current models that link assimilatory and growth processes in algae. Several responses of $\mathrm{N}$-deficient algae to $\mathrm{N}$-enrichment have been clearly established. These responses have been shown to be both time and light dependent. In the dark, $\mathrm{NH}_{4}{ }^{+}$enrichment to $\mathrm{N}$-limited cultures results in a stimulation of both $\mathrm{O}_{2}$ consumption and $\mathrm{CO}_{2}$ fixation with concomitant $\mathrm{NH}_{4}{ }^{+}$uptake (Syrett, 1953; Morris et al., 1971). In the light, uptake of transiently available $\mathrm{NH}_{4}{ }^{+}$is very rapid (Goldman and Glibert, 1982); following prolonged exposure to $\mathrm{NH}_{4}{ }^{+}$enrichment, the rate of photosynthesis is increased proportional to the $\mathrm{N}$-increment of the N-limited biomass (Healey, 1979; Goldman et al., 1981; Turpin, 1983). There is, however, no consensus on the impact of $\mathrm{N}$-enrichment on shortterm photosynthetic responses in $\mathrm{N}$-limited phytoplankton. Some researchers, working in both field and laboratory, report that limiting nutrient addition induces a temporary suppression in photosynthetic carbon fixation (Thomas et al., 1976; Collos and Slawyk, 1979; Lean and Pick, 1981; Terry, 1982; Turpin, 1983; Goldman and Dennett, 1984). Other workers have not observed this short-term effect of $\mathrm{N}$-enrich-

- Addressee for reprint requests

(C) Inter-Research/Printed in F. R. Germany ment on photosynthesis (Goldman et al., 1981; Goldman and Dennett, 1983). Most striking were the differences in results obtained using 2 strains of a marine green alga Dunaliella tertiolecta (Goldman et al., 1981; Turpin, 1983).

In this report we attempt to integrate data from several previous studies with new data in order to (a) reconcile differences in observed results, (b) consolidate and clarify the short-term photosynthetic effects of nitrogen addition to nitrogen limited microalgae and (c) to assess the usefulness of limiting nutrient induced photosynthetic suppression in the study of nutrient limitation in natural phytoplankton assemblages.

\section{MATERIALS AND METHODS}

Algal strains and culture. Two strains of Dunaliella tertiolecta Butcher were tested. 'Q1', a subclone of NEPCC-1 (Northeast Pacific Culture Collection) was obtained from the Department of Oceanography, University of British Columbia. NEPCC-1 is presumed to have originated from the 'Dun' clone. The second strain, 'Dun', was supplied courtesy of Dr. J. C. Goldman, Woods Hole Oceanographic Institute. Based on data presented in this paper it is evident that these strains are physiologically different. Both strains of $D$. tertiolecta were cultured under ammonium limitation in artificial seawater as previously described (Turpin, 1983).

$0171-8630 / 85 / 0020 / 0253 / \$ 02.50$ 
Euglena gracilis (Z), supplied courtesy of Dr. A. Yokota (University of Osaka Prefecture, Osaka, Japan), was grown in $125 \mathrm{ml}$ chemostats at $25^{\circ} \mathrm{C}$ using modified Hughes' medium (Hughes et al., 1958) enriched to $100 \mu \mathrm{M} \mathrm{NH} \mathrm{NH}_{4} \mathrm{Cl} 100 \mu \mathrm{M} \mathrm{NaH} \mathrm{PO}_{4}$ and vitamins as $\mathrm{F}$ (Guillard and Ryther, 1962).

All other species were cultured under $\mathrm{NO}_{3}{ }^{-}$limitation in $125 \mathrm{ml}$ chemostats. Synechococcus leopoliensis (UTEX 625) was grown at $30^{\circ} \mathrm{C}$ as previously described (Turpin et al., 1984). Photon flux density at the face of the cultures was $95 \mu$ Ein $\mathrm{m}^{-2} \mathrm{~s}^{-1}$. This light intensity has been shown to be growth saturating for $S$. leopoliensis under these culture conditions (Miller et al., 1984). The other species were grown in a modified Hughes' medium enriched to $100 \mu \mathrm{M} \mathrm{KNO}_{3}, 100 \mu \mathrm{M}$ $\mathrm{NaH}_{2} \mathrm{PO}_{4}$ and vitamins as $\mathrm{F} / 2$. Silicate was added as $\mathrm{Na}_{2} \mathrm{SiO}_{3}$ to a concentration of $500 \mu \mathrm{M}$ for diatom cultures. A photon flux density of $100 \mu \mathrm{Ein} \mathrm{m}^{-2} \mathrm{~s}^{-1}$ at the culture surface was maintained unless otherwise stated. Ankistrodesmus braunii (UTEX 750) was grown at $25^{\circ} \mathrm{C}$. Cyclotella meneghiniana (CYOH2) was cultured at $16^{\circ} \mathrm{C}$. Selenastrum minutum, an original isolate from Lake Ontario (1982), was grown at $20^{\circ} \mathrm{C}$.

Photosynthetic rate measurements. Two methods of measuring ${ }^{14} \mathrm{CO}_{2}$ uptake were employed in this study. (1) End Point Filtration (EPF) involved incubating culture samples for a discrete time $(15 \mathrm{~min})$ in the presence of $\mathrm{H}^{14} \mathrm{CO}_{3}$ (New England Nuclear) with or without simultaneous addition of an $\mathrm{N}$-source. Incubation was terminated by gentle filtration $(<100 \mathrm{~mm} \mathrm{Hg}$ vacuum). Filter funnels were rinsed with the appropriate growth medium, placed in a $20 \mathrm{ml}$ scintillation vial, acidified with $1.0 \mathrm{ml}$ of $1 \mathrm{~N} \mathrm{H}_{2} \mathrm{SO}_{4}$ and treated as previously described (Turpin, 1983). Dunaliella tertiolecta (both strains) were filtered onto $47 \mathrm{~mm} 0.4 \mu \mathrm{m}$ Nucleopore filters; Selenastrum minutum were filtered onto $25 \mathrm{~mm}$ Whatman $934 \mathrm{AH}$ glass fibre filters. (2) Time Series Analysis (TSA) is similar to that of Goldman et al. (1981). Culture samples were incubated in the presence of $\mathrm{H}^{14} \mathrm{CO}_{3}$ (New England Nuclear) with or without simultaneous addition of an N-source. Samples $(1.0 \mathrm{ml})$ were withdrawn at $1.0 \mathrm{~min}$ intervals and placed in $5.0 \mathrm{ml} \mathrm{mini-scintillation} \mathrm{vials} \mathrm{containing}$ $0.5 \mathrm{ml}$ of stop solution ( $66 \mathrm{ml} 95 \% \mathrm{EtOH}, 14 \mathrm{ml} \mathrm{H}_{2} \mathrm{O}$, $4 \mathrm{ml}$ formic acid). These were evaporated to dryness (Fisher Infrarediator) and acid stable ${ }^{14} \mathrm{C}$ determined as previously outlined (Goldman et al., 1981). Photosynthesis was normalized to particulate carbon (PC). Samples for particulate carbon and particulate nitrogen (PN) analysis were retained on either $25 \mathrm{~mm}$ Whatman GF/F glass fibre filters (Synechococcus leopoliensis) or $25 \mathrm{~mm}$ Whatman 934/AH glass fibre filters precombusted at $500^{\circ} \mathrm{C}$ for $24 \mathrm{~h}$. PC and $\mathrm{PN}$ measurements were made using a Control Equipment Corp. 240 XA Elemental Analyser.
$N$-source for enrichment. In all cases the concentration of added nitrogen represented $15 \%$ of inflow nitrogen concentration $(150 \mu \mathrm{M}$, Synechococcus leopoliensis; $15 \mu \mathrm{M}$, all other species). The $\mathrm{N}$-source for enrichment was the same form as that which limited growth.

\section{RESULTS AND DISCUSSION}

Goldman et al. (1981) provided data showing that ammonium addition to ammonium limited Dunaliella tertiolecta (Dun) did not affect short-term carbon fixation. Turpin (1983), however, provided additional data suggesting that short-term photosynthetic suppression followed $\mathrm{NH}_{4}{ }^{+}$addition to $\mathrm{NH}_{4}{ }^{+}$limited $D$. tertiolecta (Q1). Our results show that methodological differences do not account for the discrepancies reported for D. tertiolecta (Goldman et al., 1981; Turpin, 1983). Addition of $15 \mu \mathrm{M} \mathrm{NH}{ }_{4} \mathrm{Cl}$ to $\mathrm{N}$-limited cultures of the ' $Q 1$ ' clone resulted in a marked suppression of $\mathrm{C}$ fixation but similar enrichments to the 'Dun' clone do not affect the rate of ${ }^{14} \mathrm{C}$-uptake (Fig. 1). These results

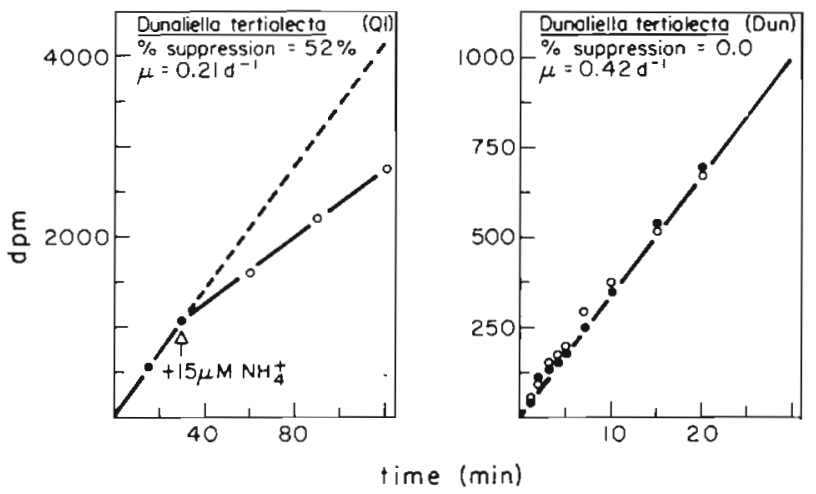

Fig. $1 .{ }^{14} \mathrm{C}$ uptake time series data (TSA) for 'Q1' and 'Dun' strains of Dunaliella tertiolecta. For ' $\mathrm{Q} 1{ }^{\prime}, \mathrm{H}^{14} \mathrm{CO}_{3}$ was added at time zero. At $30 \mathrm{~min}$, the culture was pulsed with $15 \mu \mathrm{M}$ $\mathrm{NH}_{4}{ }^{+}$. For 'Dun' experiments, parallel cultures were initiated at time zero by addition of $\mathrm{H}^{14} \mathrm{CO}_{3}$ with simultaneous addition of $15 \mu \mathrm{M} \mathrm{NH}_{4}{ }^{+}$to one. Closed circles: controls with no added $\mathrm{N}$-source; open circles: samples taken following enrichment with $15 \mu \mathrm{M} \mathrm{NH}{ }_{4}^{+}$. Different specific activities were used for each strain to accommodate desired experimental time frames

are entirely consistent with those previously reported by both Goldman et al. (1981) and Turpin (1983). The observed suppression with the 'Q1' strain is observed using both EPF (Turpin, 1983) and TSA (this study) measurements of $\mathrm{C}$-fixation. Both these techniques give identical estimates of photosynthesis (Table 1). Our data suggest that the discrepancies reported for D. tertiolecta (Goldman et al., 1981; Turpin, 1983) are due to differing photosynthetic responses to limiting nutrient addition of these two strains. 
Table 1. Effect of $15 \mu \mathrm{M} \mathrm{NH} \mathrm{NH}_{4} \mathrm{Cl}$ on short-term photosynthetic carbon fixation ( \pm SE) in Dunaliella tertiolecta (Dun) determined by the filtration technique and from a linear regression on the acidified time series data of Fig. 1. Ammonium limited growth rate was $\mu=0.42 \mathrm{~d}^{-1}$ corresponding to $46 \% \mu_{\max }$

\begin{tabular}{|lccc|}
\hline Method & $\begin{array}{c}\text { Control } \\
(\mu g C \\
\mathrm{l}^{-1} \mathrm{~h}^{-1}\end{array}$ & $\begin{array}{c}+15 \mu \mathrm{M} \\
\mathrm{NH}_{4}^{+}(\mu \mathrm{gC} \\
\left.\mathrm{l}^{-1} \mathrm{~h}^{-1}\right)\end{array}$ & $\begin{array}{c}\% \\
\text { Sup- } \\
\text { pression }\end{array}$ \\
\hline End point filtration & $234 \pm 9$ & $249 \pm 4$ & 0 \\
Time series analysis & $241 \pm 5$ & $236 \pm 6$ & 0 \\
\hline
\end{tabular}

Table 2. Photosynthetic suppression induced by nitrate or ammonium addition to nitrate limited cultures of Selenastrum minutum. Maximal growth rate is $1.68 \mathrm{~d}^{-1}$

\begin{tabular}{|c|c|c|c|c|}
\hline \multirow[t]{3}{*}{$\begin{array}{c}\mu \\
\left(d^{-1}\right)\end{array}$} & \multirow[t]{3}{*}{$\begin{array}{c}\% \\
\mu_{\max }\end{array}$} & \multicolumn{3}{|c|}{$\begin{array}{c}\% \text { Suppression of photosynthetic } \\
\text { carbon fixation }\end{array}$} \\
\hline & & \multirow{2}{*}{$\begin{array}{c}\begin{array}{c}\text { Time series } \\
\text { analysis }\end{array} \\
\left(\begin{array}{c}15 \mu \mathrm{M} \\
\mathrm{NO}_{3}\end{array}\right)\end{array}$} & \multicolumn{2}{|c|}{ End point filtration } \\
\hline & & & $\begin{array}{c}(+15 \mu \mathrm{M} \\
\left.\mathrm{NO}_{3}\right)\end{array}$ & $\begin{array}{c}(+15 \mu \mathrm{M} \\
\left.\mathrm{NH}_{4}{ }^{+}\right)\end{array}$ \\
\hline 0.30 & 18 & 66.7 & 70.0 & 20.0 \\
\hline 0.42 & 25 & 77.1 & 69.1 & 39.2 \\
\hline 0.51 & 30 & 63.9 & 61.4 & 44.5 \\
\hline 0.87 & 52 & 61.4 & 63.5 & 36.6 \\
\hline 1.2 & 71 & 17.8 & 33.0 & NA \\
\hline 1.47 & 88 & 12.4 & 12.5 & 8.4 \\
\hline 1.68 & 100 & 0.0 & 0.0 & 0.0 \\
\hline
\end{tabular}

Preliminary work with Selenastrum minutum has shown that addition of nitrate or ammonium to nitrate limited chemostats also results in a major suppression of C-fixation. The magnitude of this suppression is independent of the method employed to measure ${ }^{14} \mathrm{C}$ accumulation (Table 2). Photosynthetic suppression upon enrichment is greatest at low relative growth rates but drops to zero at high relative growth rates where the cells are no longer nitrogen limited. While addition of either $\mathrm{NO}_{3}{ }^{-}$or $\mathrm{NH}_{4}{ }^{+}$to $\mathrm{S}$. minutum suppressed $\mathrm{C}$-fixation, $\mathrm{NO}_{3}{ }^{-}$consistently caused a greater suppression in photosynthesis. It has been postulated that suppression of ${ }^{14} \mathrm{C}$-fixation upon nitrogen addition may be the result of competition for photochemically generated ATP and reductant between the processes of nitrogen assimilation and photosynthetic carbon fixation (Falkowski and Stone, 1975). Eight electrons are required for the assimilatory reduction of $\mathrm{NO}_{3}{ }^{-}$to $\mathrm{NH}_{4}{ }^{+}$(Losada et al., 1981; Falkowski, 1983). This added requirement for reducing power during rapid new nitrogen assimilation would cause a greater suppression of $\mathrm{C}$-fixation for $\mathrm{NO}_{3}{ }^{-}$enrichment than for $\mathrm{NH}_{4}{ }^{+}$enrichment, if the competition hypothesis is cor- rect. The data presented here, taken alone, support the idea that the processes of nitrogen assimilation and C-fixation compete for photochemically generated reducing power. The difference between $\mathrm{NO}_{3}{ }^{-}$and $\mathrm{NH}_{4}{ }^{+}$induced suppression, however, may simply be the result of low $\mathrm{NH}_{4}{ }^{+}$transport activity since $\mathrm{NO}_{3}{ }^{-}$ grown cells may not have induced high concentrations of the $\mathrm{NH}_{4}{ }^{+}$transporter. The physiology of $\mathrm{NH}_{4}{ }^{+}$ grown cells is currently under further study. Alternately, the different results obtained with $\mathrm{NO}_{3}{ }^{-}$and $\mathrm{NH}_{4}{ }^{+}$may reflect different mechanisms underlying photosynthetic suppression caused by $\mathrm{NO}_{3}{ }^{-}$or $\mathrm{NH}_{4}{ }^{+}$. It has been well established that large changes in metabolism occur upon $\mathrm{NH}_{4}{ }^{+}$addition, while the effect of $\mathrm{NO}_{3}{ }^{-}$addition is variable (Kanazawa et al., 1970a; Grant et al., 1972; Bassham et al., 1981).

The effect of limiting nutrient addition on photosynthetic C-fixation varies widely and appears to be species specific. The results presented in Fig. 2 show responses ranging from an absence of suppression in Ankistrodesmus braunii to $66.7 \%$ suppression in Selenastrum minutum. Cyclotella meneghiniana, Euglena gracilis, Synechococcus leopoliensis and $S$. minutum all exhibited some degree of photosynthetic suppression in response to nitrogen addition. At the dilution rates maintained in this study, the relative growth rates established were such that observed suppressions were maximal (Turpin, 1983). The ratio of $\mu^{\prime} \mu^{-1}$ (Li and Goldman, 1981) approximated the expected steady state value of 1.0 for all cultures except $C$. meneghiniana where ${ }^{14} \mathrm{C}$ accumulation $\left(\mu^{\prime}\right)$ clearly underestimated steady state growth rate $(\mu)$. There are great differences between species in the degree to which C-fixation is affected by N-enrichment under N-limitation. The physiological significance of these differences is unclear and currently under further study.

Data from the 5 species tested here and from other reports indicate that the suppression phenomenon is taxonomically widely distributed in both freshwater and marine phytoplankton (Table 3). The suppression response, however, is not universal and in some cases is not found in related species of the same family, as in Ankistrodesmus braunii and Selenastrum minutum (this study), or even in related strains of the same species such as Dunaliella tertiolecta (Goldman et al., 1981; Turpin, 1983); Phaeodactylum tricornutum (Collos and Slawyk, 1979; Goldman et al., 1981; Terry, 1982); Thalassiosira weissflogii (Goldman et al., 1981; Terry, 1982) (Table 3). How such different physiological responses can be seen in such taxonomically closely related populations is puzzling and of physiological interest.

It has been argued (Goldman and Dennett, 1983) that species exhibiting photosynthetic suppression may 

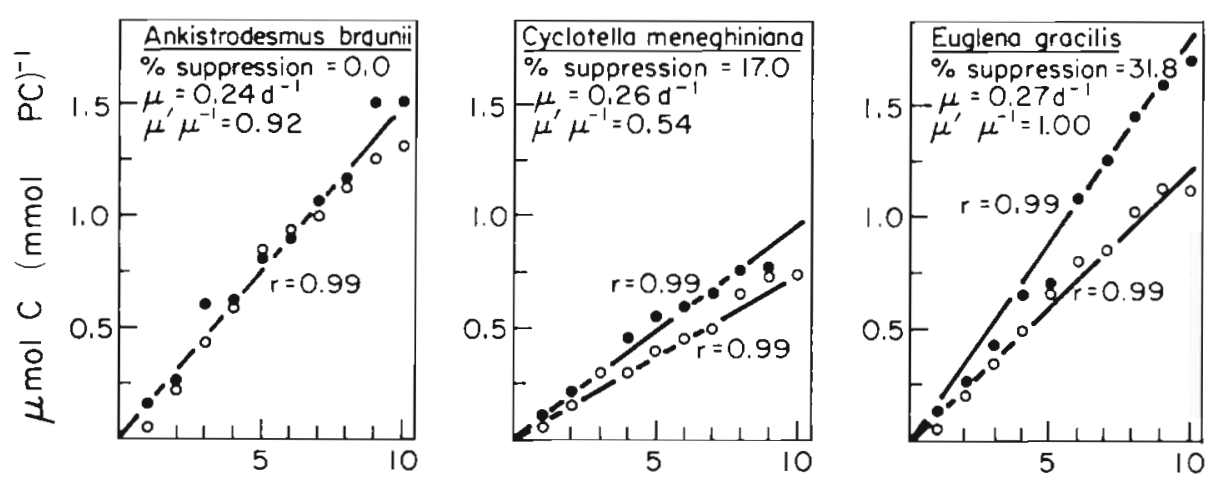

Fig. $2,{ }^{14} \mathrm{C}$ uptake time series data (TSA) for 5 freshwater phytoplankton species of wide taxonomic diversity. Experiments for parallel cultures were initiated at time zero by addition of $\mathrm{H}^{14} \mathrm{CO}_{3}$ with simultaneous addition of an $\mathrm{N}$-source (see text) to one. Closed circles: controls; open circles: enriched cultures. Units expressed as $\mu$ moles carbon assimilated per mmole particulate carbon ( $\mu \mathrm{mol} \mathrm{C}$ mmol $\mathrm{PC}^{-1}$ ). For species exhibiting photosynthetic suppression, differences in the slopes of plotted regression lines are significant at the $\mathrm{p}<0.001$ confidence level using the homogeneity of slopes test

suffer a competitive disadvantage relative to non-suppressing species in mixed assemblages. The amount of carbon 'not fixed' relative to the control during the period of suppression has been calculated for $15 \mu \mathrm{M}$ $\mathrm{NH}_{4}{ }^{+}$addition in Dunaliella tertiolecta (Q1) and $15 \mu \mathrm{M} \mathrm{NO}_{3}{ }^{-}$addition in Selenastrum minutum. The maximal amount of carbon not fixed during the period of suppression represents $1.2 \%$ ( $S$. minutum) to $2 \%$ (D. tertiolecta [Q1]) of the total PC biomass. During the period of enhanced carbon fixation following suppression, this 'lost carbon' is replaced within the first few hours. Since this enhanced photosynthesis continues for at least $24 \mathrm{~h}$ following enrichment (Turpin, 1983), the carbon not fixed during the period of suppression constitutes a very small amount relative to the total net carbon gain following nitrogen addition. It therefore seems that there is no reason a priori to assume that the transient photosynthetic suppression would be a competitive disadvantage.

It is important to distinguish between $\mathrm{CO}_{2}$ fixation and $\mathrm{O}_{2}$ evolution as separate components of photosynthesis with regard to this phenomenon. The majority of data presented here have bearing on C-fixation only. While Healey (1979) reports suppression of $\mathrm{O}_{2}$ production following nitrogen enrichment, some preliminary results from our laboratory suggest that changes in $\mathrm{O}_{2}$ evolution are not necessarily concomitant with changes in $\mathrm{CO}_{2}$ uptake. As noted by Turpin (1983), decreased $\mathrm{O}_{2}$ evolution concurrent with $\mathrm{C}$-fixation suppression would not be expected if the underlying mechanism for suppression is a competition for ATP and reductant between nitrogen and carbon assimilation.

There are several reports suggesting use of limiting nutrient induced photosynthetic suppression to evaluate nutrient limitation of phytoplankton growth in the field (Gerhart and Likens, 1975; Lean and Pick, 1981; Lean et al., 1982; Turpin, 1983). The observed variability in species response to limiting nutrient addition underscores the difficulty in using this phenomenon as an indicator of nutrient deficiency in natural systems. Because responses to limiting nutrient addition are species or strain specific and previous life history has a major effect in regulating photosynthetic C-fixation upon enrichment, assessment of nutrient deficiency by comparison of unenriched and enriched short-term ${ }^{14} \mathrm{C}$ incubations may not provide a quantitative estimate of nutrient limitation. Furthermore, enrichment of ${ }^{14} \mathrm{C}$ incubated samples followed by single end point determinations of ${ }^{14} \mathrm{C}$ accumulation may 'mask' simultaneously enhanced C-fixation in some cells and suppressed C-fixation in others. Moreover, the problem is compounded by the necessity for long incubations due to low biomass in oligotrophic systems where nutrients are most likely to be limiting. We conclude that absence of nitrogen limited photosynthetic suppression in a natural sample does not preclude the possibility of nitrogen limitation. It is most likely, however, that if 
Table 3. Transient photosynthetic response of nitrogen limited microalgae to nitrogen addition ${ }^{a}$

\begin{tabular}{|c|c|c|c|c|c|c|c|}
\hline Division & Species & Habitat & $\begin{array}{l}\text { Growth } \\
\mathrm{N} \text {-source }\end{array}$ & $\begin{array}{l}\text { Enriched } \\
\mathrm{N} \text {-source }\end{array}$ & $\begin{array}{l}\text { Observed } \\
\text { suppression }\end{array}$ & Method & Reference \\
\hline Cyanophyta & $\begin{array}{l}\text { Synechococcus } \\
\text { leopoliensis } \\
\text { (UTEX 625) }\end{array}$ & $\mathrm{F}$ & $\mathrm{NO}_{3}^{-}$ & $\mathrm{NO}_{3}{ }^{-}$ & yes & $\mathrm{TSA}^{\mathrm{b}}$ & This study \\
\hline \multirow[t]{8}{*}{ Chrysophyta } & $\begin{array}{l}\text { Cyclotella } \\
\text { meneghiniana } \\
\text { (CYOH2) }\end{array}$ & F & $\mathrm{NO}_{3}^{-}$ & $\mathrm{NO}_{3}^{-}$ & yes & TSA & This study \\
\hline & $\begin{array}{l}\text { Phaeodactylum } \\
\text { tricornutum (HIMB) }\end{array}$ & M & $\mathrm{NO}_{3}^{-}$ & $\mathrm{NO}_{3}^{-}$ & yes & EPS $^{\mathrm{c}}$ & Terry (1982) \\
\hline & $\begin{array}{l}\text { Phaeodactylum } \\
\text { tricornutum Bohlin } \\
\text { (SMF) }\end{array}$ & M & $\mathrm{NO}_{3}^{-}$ & $\mathrm{NO}_{3}{ }^{-}, \mathrm{NO}_{2}{ }^{-}$ & yes & $13^{d}$ & $\begin{array}{l}\text { Collos \& Slawyk } \\
(1979)\end{array}$ \\
\hline & $\begin{array}{l}\text { Phaeodactylum } \\
\text { tricornutum (TFX-1) }\end{array}$ & M & $\mathrm{NH}_{4}^{+}$ & $\mathrm{NH}_{4}{ }^{+}$ & no & TSA & $\begin{array}{l}\text { Goldman et al. } \\
\text { (1981) }\end{array}$ \\
\hline & $\begin{array}{l}\text { Chaetoceros } \\
\text { simplex (BBsm) }\end{array}$ & M & $\begin{array}{c}\mathrm{NH}_{4}^{+}, \mathrm{NO}_{3}^{-} \\
\text {urea }\end{array}$ & $\begin{array}{c}\mathrm{NH}_{4}{ }^{+} \mathrm{NO}_{3}^{-} \\
\text {urea }\end{array}$ & no & TSA & $\begin{array}{l}\text { Goldman et al. } \\
\text { (1981); Goldman \& } \\
\text { Dennett (1983) }\end{array}$ \\
\hline & $\begin{array}{l}\text { Thalassiosira } \\
\text { weissflogii (Actin) }\end{array}$ & M & $\mathrm{NH}_{4}^{+}$ & $\mathrm{NH}_{4}{ }^{+}$ & no & TSA & $\begin{array}{l}\text { Goldman et al. } \\
\text { (1981) }\end{array}$ \\
\hline & $\begin{array}{l}\text { Thalassiosira } \\
\text { weissflogii } \\
\text { (FCRGCC/Scripps) }\end{array}$ & M & $\mathrm{NO}_{3}^{-}$ & $\mathrm{NO}_{3}^{-}$ & yes & EPS & Тепту (1982) \\
\hline & $\begin{array}{l}\text { Skeletonema } \\
\text { costatum (SMd'EC) }\end{array}$ & M & $\begin{array}{l}\mathrm{NO}_{3}^{-}, \mathrm{NO}_{2}^{-} \\
\mathrm{NH}_{4}^{+}, \text {urea }\end{array}$ & $\begin{array}{c}\mathrm{NO}_{3}{ }^{-}, \mathrm{NO}_{2}{ }^{-} \\
\text {urea }\end{array}$ & yes & $13_{C}$ & $\begin{array}{l}\text { Collos \& Slawyk } \\
(1979)\end{array}$ \\
\hline Euglenophyta & Euglena gracilis $(\mathrm{Z})$ & $\mathrm{F}$ & $\mathrm{NO}_{4}^{+}$ & $\mathrm{NO}_{4}^{+}$ & yes & TSA & This study \\
\hline \multirow[t]{7}{*}{ Chlorophyta } & $\begin{array}{l}\text { Chlorella fusca var. } \\
\text { vacuolata }(211 / 8 p)\end{array}$ & $\mathrm{F}$ & $\mathrm{NO}_{3}{ }^{-}$ & $\mathrm{NO}_{3}^{-}, \mathrm{NO}_{2}^{-}$ & yes & EPS & $\begin{array}{l}\text { Thomas et al. } \\
(1976)\end{array}$ \\
\hline & $\begin{array}{l}\text { Chlamydomonas } \\
\text { reinhardtii }\end{array}$ & $\mathrm{F}$ & $\mathrm{NO}_{3}^{-}$ & $\mathrm{NH}_{4}{ }^{+}$ & yes & $\mathrm{O}_{2}{ }^{\mathrm{e}}$ & Healey (1979) \\
\hline & $\begin{array}{l}\text { Scenedesmus } \\
\text { quadricauda }\end{array}$ & $\mathrm{F}$ & $\mathrm{NO}_{3}^{-}$ & $\mathrm{NH}_{4}{ }^{+}$ & yes & $\mathrm{O}_{2}$ & Healey (1979) \\
\hline & $\begin{array}{l}\text { Ankistrodesmus } \\
\text { braunii Brun. } \\
\text { (UTEX 750) }\end{array}$ & $\mathrm{F}$ & $\mathrm{NO}_{3}^{-}$ & $\mathrm{NO}_{3}{ }^{-}$ & no & TSA & This study \\
\hline & $\begin{array}{l}\text { Selenastrum } \\
\text { minutum (original } \\
\text { isolate from lake } \\
\text { Ontario, 1982) }\end{array}$ & $\mathrm{F}$ & $\mathrm{NO}_{3}^{-}$ & $\mathrm{NO}_{3}{ }^{-}, \mathrm{NH}_{4}{ }^{+}$ & yes & $\mathrm{EPF}^{\mathrm{f}}, \mathrm{TSA}$ & This study \\
\hline & $\begin{array}{l}\text { Dunaliella } \\
\text { tertiolecta }(\mathrm{Q} 1)\end{array}$ & M & $\mathrm{NH}_{4}^{+}$ & $\mathrm{NH}_{4}{ }^{+}$ & yes & EPF, TSA & $\begin{array}{l}\text { Turpin (1983); this } \\
\text { study }\end{array}$ \\
\hline & $\begin{array}{l}\text { Dunaliella } \\
\text { tertiolecta (Dun) }\end{array}$ & $M$ & $\mathrm{NH}_{4}{ }^{+}$ & $\mathrm{NH}_{4}^{+}$ & no & TSA & $\begin{array}{l}\text { Goldman et al. } \\
(1981) ; \text { this study }\end{array}$ \\
\hline \multicolumn{8}{|c|}{ 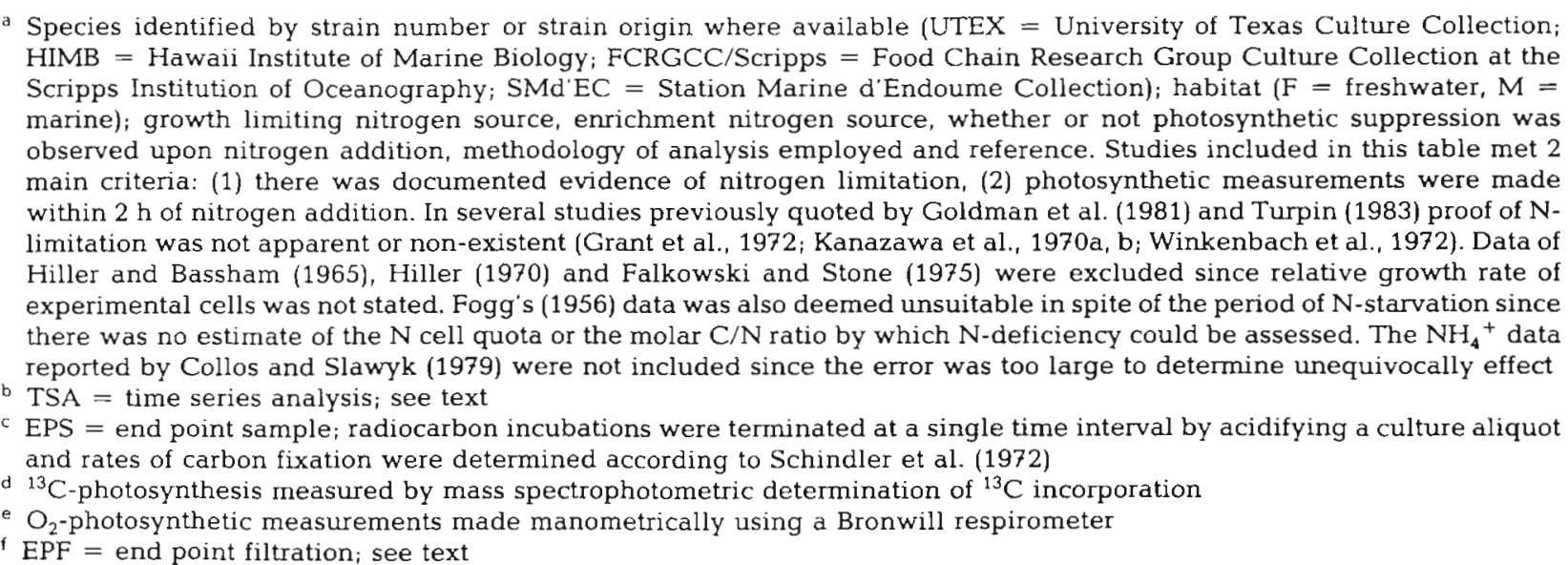 } \\
\hline
\end{tabular}


this phenomenon is observed, nitrogen is limiting the growth of certain species in the assemblage.

Acknowledgements. We thank Drs. D. B. Layzell and A. G. Miller for helpful discussions. This study was supported by the Natural Sciences and Engineering Research Council of Canada and the Advisory Research Committee of Queen's University.

\section{LITERATURE CITED}

Allen, M. M. (1968). Simple conditions for the growth of unicellular blue-green algae in plates. J. Phycol. 4: 1-4

Bassham, J. A., Larsen, P. O., Lawyer, A. L., Comell, K. L. (1981). Relationships between nitrogen metabolism and photosynthesis. In: Bewley, J. D. (ed.) Nitrogen and carbon metabolism. Mastinus Nijhoff/Dr. W. Junk, London, p. $135-163$

Collos, Y., Slawyk, G. (1979). ${ }^{13} \mathrm{C}$ and ${ }^{15} \mathrm{~N}$ uptake by marine phytoplankton. I. Influences of nitrogen source and concentration in laboratory cultures of diatoms. J. Phycol. 15 $186-190$

Falkowski, P. G., Stone, D. P. (1975). Nitrate uptake in marine phytoplankton: energy sources and the interaction with carbon fixation. Mar. Biol. 32: 77-84

Falkowski, P. G. (1983). Enzymology of nitrogen assimilation. In: Carpenter, G. J., Capone, D. G. (ed.) Nitrogen in the marine environment. Academic Press, New York, p. 839-868

Fogg, G. E. (1956). Photosynthesis and formation of fats in a diatom. Ann. Bot. 20: 265-285

Gerhart, D. Z., Likens, G. E. (1975). Enrichment experiments for determining nutrient limitation: four methods compared. Limnol. Oceanogr. 20:649-653

Goldman, J. C., Dennett, M. R., Riley, C. B. (1981). Marine phytoplankton photosynthesis and transient ammonium availability. Mar. Biol. Lett. 2: 323-331

Goldman, J. C., Glibert, P. M. (1982). Comparative rapid ammonium uptake by four species of marine phytoplankton. Limnol. Oceanogr. 27: 814-828

Goldman, J. C., Dennett, M. R. (1983). Effect of nitrogen source on short term light and dark $\mathrm{CO}_{2}$ uptake by a marine diatom. Mar. Biol. 76: 7-15

Goldman, J. C., Dennett, M. R. (1984). Photosynthetic responses of 15 phytoplankton species to ammonium pulsing. Mar. Ecol. Prog. Ser. 20: 259-264

Grant, B. R., Winkenbach, F., Canvin, D. T., Bidwell, R. G. S (1972). The effect of nitrate, nitrite and ammonia on photosynthesis by Acetabularia chloroplast preparations compared with spinach chloroplasts and whole cells of Acetabularia and Dunaliella. Can. J. Bot. 50: 2535-2543

Guillard, R. R. L., Ryther, J. H. (1962). Studies on marine diatoms I. Cyclotella nana Hustedt and Detonula confervacea (Cleve). Gran. Can. J. Microbiol. 8: 229-39

Healey, F. P. (1979). Short-term responses of nutrient deficient algae to nutrient addition. J. Phycol. 15: 289-299

Hiller, R. G. (1970). Transients in the photosynthetic carbon reduction cycle produced by iodoacetic acid and ammonium chloride. J. exp. Bot. 21:628-38

Hiller, R. G., Bassham, J. A. (1965). Inhibition of $\mathrm{CO}_{2}$ fixation by nitrous acid. Biochim. biophys. Acta 109: 607-610
Hughes, E. O., Gorham, P. R, Zender, A. (1958). Toxicity of a unialgal culture of Microcystis aeruginosa. Can. J. Microbiol. 4: 225-236

Kanazawa, T., Kirk, M. R., Bassham, J. A. (1970a). Regulatory effects of ammonia on carbon metabolism in photosynthesizing Chlorella pyrenoidosa. Biochim. biophys. Acta 205: 401-408

Kanazawa, T., Kanazawa, K., Kirk, M. R., Bassham, J. A. (1970b). Difference in nitrate reduction in 'light' and 'dark' stages of synchronously grown Chlorella pyrenoidosa and resultant metabolic changes. Plant Cell Physiol. 11: 445-452

Lean D. R. S., Pick, F. R. (1981). Photosynthetic response of lake phytoplankton to nutrient enrichment: a test for nutrient limitation. Limnol. Oceanogr. 26: 1001-1019

Lean, D. R. S., Murphy, T. P., Pick, F. R. (1982). Photosynthetic response of lake plankton to combined nitrogen enrichment. J. Phycol. 18: 509-521

Lehman, J. T., Scavia, D. (1982). Microscale patchiness of nutrients in plankton communities. Science, N. Y. 216: $729-730$

Li, W. K. W., Goldman, J. C. (1981). Problems in estimating growth rates of marine phytoplankton from short term ${ }^{14} \mathrm{C}$ assays. Microbiol. Ecol. 7: 113-121

Losada, M., Guerrero, M. G., Vega, J. M. (1981). The

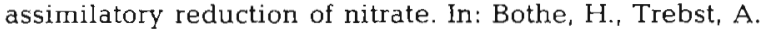
(ed.) The biology of inorganic nitrogen and sulfur. Springer-Verlag, New York, p. 30-64

Miller, A. G., Turpin, D. H., Canvin, D. T. (1984). Growth and photosynthesis of the cyanobacterium Synechococcus leopoliensis in $\mathrm{HCO}_{3}$-limited chemostats. Pl. Physiol. 75: $1064-1070$

Morris, I., Yentsch, C. S., Yentsch, C. M. (1971). The physiological state with respect to nitrogen of phytoplankton from low nutrient subtropical water as measured by the effect of the ammonium ion on dark carbon dioxide fixation. Limnol. Oceanogr. 16: 859-868

Schindler, D. W., Schmidt, R. V., Reid, R. A. (1972). Acidification and bubbling as an alternative to filtration in determining phytoplankton production by the ${ }^{14} \mathrm{C}$ method. J. Fish. Res. Bd Can. 29: 1627-1631

Syrett, P. J. (1953). The assimilation of armmonia by nitrogen starved cells of Chlorella vulgaris. Part I. The correlation of assimilation with respiration. Ann. Bot. (Lond.) 65: 1-19

Terry, K. L. (1982). Nitrate uptake and assimilation in Thalassiosira weissflogii and Phaeodactylum tricornutum: interactions with photosynthesis and with the uptake of other ions. Mar. Biol. 62: 21-30

Thomas, R. J., Hipkin, C. R., Syrett, P. J. (1976). The interaction of nitrogen assimilation with photosynthesis in nitrogen deficient cells of Chlorella. Planta 133: 9-13

Turpin, D. H. (1983). Ammonium induced photosynthetic suppression in ammonium limited Dunaliella tertiolecta (Chlorophyta). J. Phycol. 19: 70-76

Turpin, D. H., Miller, A. G., Canvin, D. T. (1984). Carboxysome content of Synechococcus leopoliensis (Cyanophyta) in response to inorganic carbon. J. Phycol. 20: 249-253

Winkenbach, F., Grant, B. R., Bidwell, R. G. S. (1972). The effects of nitrate, nitrite and ammonia on photosynthetic carbon metabolism of Acetabularia chloroplast preparations compared with spinach chloroplasts and whole cells of Acetabularia and Dunaliella. Can. J. Bot. 50: 2545-2551 